\title{
A Study of Errors Arising from Property Investment Income Capitalization Techniques
}

\begin{abstract}
Abayomi.0. Ibiyemi
Martins.T.A Adenipekun

Dept. of Estate Management, Lagos State Polytechnic, Lagos, Nigeria Tel: 0802.261.9693; yomi1004@gmail.com

Doi:10.5901/mjsss.2013.v4n6p639

Abstract

This paper reviews a compendium of the valuers' techniques, such as the Contractor's test, Sales comparison, and the income capitalization and attempts to highlight the probable errors and shortcomings of the income capitalisation techniques, which is the most commonly used by them. These errors are found in the treatment of taxation, allowance for sinking fund, use of allrisks yields, allowance for risks on the basis of Risk Adjusted Discount Facto (RADF), and the implicit rental growth conventional valuation concept. Contemporary models for allowance of Capital Gains Tax (CGT) in freehold valuations, Double Sinking Fund (DSF), Equivalent Yield, and Risk and Explicit Rental Growth Adjustment are briefly considered with illustrations. This paper seeks to encourage students and lecturers to update their knowledge content of these models, and also compel valuation surveyors to step up their applications in valuation practice in Nigeria.
\end{abstract}

Keywords: Errors, CGT, DSF,ARY, Freehold Valuation, Leaseholds, RADF

\section{Introduction}

Real estate appraisers attempt to derive market value: "The most probable price in terms of money which a property should bring in a competitive and open market under all conditions requisite to a fair sale, the buyer and seller, each acting prudently, knowledgeably and assuming the price is not affected by undue stimulus." They generally use three approaches: The Cost Approach, Sales Comparison, and the Income Capitalisation Approach. All the three approaches use information on market transactions to derive value conclusions. The Cost Approach is based upon the premise that the value of a property is approximated by the investment necessary to replace or substitute that property. Replacement costs typically include land acquisition, the cost of site and building improvements, and an allowance for the developer's profit, less accrued depreciation. The Sales Comparison Approach is derived from sales of properties similar to the subject, each of which is compared to the property appraised and adjusted to reflect the estimated influence of various characteristics.

There are two basic forms of income approaches: The Income Capitalization and Discounted Cash Flow. Income Capitalization is a process of measuring future income and translating this income into a total value via capitalization. In employing the Income Capitalization Method, consideration is given to the earning capacity of the property over an anticipated period of time. This time element is measured by an appropriate discount rate commensurate with risk and equity requirements. The time element is revealed in the study of investors activity with respect to the type of property being appraised, as well as in broader measures of investor requirements. Discounted Cash Flow Analysis incorporates year-by-year projections of income and expenses, discounts these cash flows by an appropriate rate, and adds the present value of a sale at some future date.

The paper identifies probable errors and shortcomings of the income capitalization techniques on the basis of the notion that valuations are central to performance measurement and pricing in the property industry. It is also relevant at this moment in time when new sophisticated investors that would emerge from the Government's liberalization policy and local valuation service users are beginning to query the valuers' rationality and reliability in the investment market.

\section{Sources of Errors}

- $\quad$ Capital Gains Tax (CGT) provisions in Freehold Valuations 
- Multiple provisions of sinking funds

- $\quad$ Use of All-Risks Yields (ARY)

- Application of Implicit Income Capitalization

- $\quad$ Lack of Environmental Considerations

\section{CGT and Freehold Property Valuation}

Income taxation is often ignored in freehold property valuations for two major reasons:

(a) The argument that all incomes, including from all types of landed property are subject to income tax, and insofar as every other type of investment income is subject to income tax, it is customary in valuation to ignore the effects of taxation.

(b) The other ground is that investors compare investments on the basis of their gross rates of return. Hence it is said that if the effect of tax on income is neglected in all cases, there will be no material difference in the results. This may well be an acceptable criterion where tax affects all investments and all investors in a like manner

However, it is important to note that where the income from property is all return on capital i.e. true spendable income (as is the case for freehold incomes), gross and net valuation will produce the same value estimate. But where part of the income is a part return on capital (as is the case for leasehold incomes/ profit rents) and that part is not exempt from taxation, then in such cases, the net and gross approaches may produce a different value estimate.

More importantly, certain freehold properties will produce substantial growth in capital value over a relatively short term, due to growth in income. In these cases, if the investment is resold, CGT may be payable on the gain realized. For example, where it is required to value the freehold interest in say, a shop in a $1^{\text {st }}$ class position let to a multiple on an FRI lease with 3 years to run: Present Rent $=$ N3,000 and the full rental value N5,000.00. The prospect of a CGT must be taken into account, since the purchase price NOW will be less than the value of 3 years time The incidence of CGT cannot be ignored here. Error is introduced by assuming that the capital gain arises on the whole of the reversionary income $(\mathrm{N} 5,000)$ whereas in fact, the increasing income which produces the CGT is N5,000 - N3,000, giving a Capital Gain of N2,000.

To illustrate this point, let us consider three valuation scenarios: The normal valuation without tax allowance, valuation with allowance for CGT, and the hardcore/layer model.

Our normal valuation will be:

\section{Part A - Term}

Next 3 years

Rent received

YP 3 years at $5 \frac{1}{2} \%$

\section{Part B - Reversion}

Reversion to FRV

YP r.p. def'd 3years at $6 \%$
N3,000 p.a N8,094

$\mathrm{N} 5,000$

$\frac{14}{N 70,000}$

Say, N78,000

Part B of the calculation is the short cut method of saying (N5,0000 x YP perp at 6\%) X PV of N1 in 3years at 6\% i.e.

Rent receivable

YP perp at $6 \%$

$\mathrm{N} 5,000 \mathrm{pa}$

16.67

$\mathrm{N} 83,300$

$\mathrm{PV}$ of $\mathrm{N} 1$ in $3 y r s$ at $6 \%$

0.8396

$\mathrm{N} 70,000$

The investor will pay N70,000 now in order to receive N83,300 in 3years, time, thus making a capital gain of N13,300. (N83,300 - N70,000).

Applying the theory of net interest rate, an obvious method of allowing for tax is to make the valuation as follows:

Term as before

N8,094 


\begin{tabular}{|c|c|c|}
\hline $\begin{array}{l}\text { Reversion } \\
\text { YP perp at } 6 \%\end{array}$ & & $\begin{array}{l}N 5,000 \\
16,67\end{array}$ \\
\hline $\mathrm{XPV}$ of $\mathrm{N} 1$ in 3 years & & \\
\hline at $6 \%$ (tax at $40 \%)$ & $\underline{0.899}$ & 15 \\
\hline
\end{tabular}

The most casual inspection of these results show that it is unrealistic in that investor is being asked to pay N83,000 now for a freehold which, free of the encumbrance of lease, is worth only N83,300 in 3years' time. The error is introduced because we have assumed that the capital gain arises on the whole of the reversionary income $(N 5,000)$ whereas, the increasing income which produces the CGT is N5,000 - N3,000, giving a Capital Gain of N2,000.

The hardcore model attempts to correct this error as follows:

Using the same example: Preliminary

\begin{tabular}{|c|c|c|c|}
\hline \multirow[t]{2}{*}{ Stage l: } & FRV & N5,00C & \multirow{3}{*}{83,335} \\
\hline & YP perp at $6 \%$ & 18.67 & \\
\hline Stage II: & Existing Rent & $\mathrm{N} 3,00 \mathrm{C}$ & \\
\hline & \multicolumn{2}{|c|}{ YP perp at $51 / 2 \%$} & $\frac{18.82}{\underline{54,546}}$ \\
\hline & $\mathrm{CV}$ of mar & ncome & N28,789 \\
\hline
\end{tabular}

Stage III: $\quad \begin{aligned} \text { Marginal income } & \times 100 \\ \frac{2,000}{28,789} \times 100 & =7 \%\end{aligned}$

Valuation

Hardcore income N3,000

YP perp at $5^{1 / 2} \%$

Marginal income

YP perp. @ 7\%

14.286

PV of N1in 3 yrs @

$7 \%$ (GCT at 40\%)

$\underline{0.884}$

$\frac{12.6}{\mathrm{C} . \mathrm{V}} \quad \frac{\mathrm{N} 25.200}{\mathrm{~N} 79,750}$

The investor on CGT at 40\%, using the hardcore or layer model, will be ask to pay N79,750 for a freehold which, free of encumbrance of the lease, is worth N83,300. This appears realistic. The dual yields for the term and reversion was further harmonized by the use of IRR-oriented equivalent yield.

\section{Multiple provisions of Sinking Funds}

The normal method of valuing varying profit rentals is mathematically incorrect. The answers depends on the combination of all the variables (splitting combination, remunerative and accumulative rates adjusted for tax, the total length of term, and the manner in which it is let)

Consider the valuation of profit rental of N1,000 pa available for 21years, our normal valuation will be :

(a) Valuation II A

Profit rent

N1000ps

YP 21 years @ 9/3\%

( tax @ 40\%)

$\mathrm{N} 54,546$

2,000

$\underline{6.695} \underline{N 6,695}=$

Splitting the term as above (14 \& 7 years)

Our normal valuation will be :

(b) Valuation II B 


$$
\begin{array}{lc}
\text { First 14 years : } & \text { Profit Rent } \quad \begin{array}{l}
\text { N1000 pa } \\
\text { YP 14years @ 9/3 }
\end{array} \\
& (\operatorname{tax} @ 40 \%) \quad \underline{5.274}
\end{array}
$$

Next 7years: $\quad$ Profit Rent N1000pa

YP 7yrs @ 9 / 3 (tax @ 40\%) 3.204

PV of NI in 14 yrs @ 9\% $\underline{0.299} \underline{0.96} \quad-\quad \underline{960=}$

\section{Splitting the term at say, 7years and 14years}

Our normal valuation will be :

\section{(c) Valuation II C}

First 7years: Profit Rent

YP 7yrs @ 9 / 3\% (tax @ 40\%)

$\mathrm{N} 1,000 \mathrm{pa}$

$$
\text { N3,204 }
$$

3.204

Next 14years :Profit Rent

$$
\text { N1,000 }
$$

$$
\text { (tax@ 40\%) } 5.274
$$$$
\text { PV of NI in } 7 \text { yrs @ 9\% } \underline{0.547}
$$

$N 5,274=$

$\underline{960=}$

\section{$\underline{N 6,234}=$}

This example shows that the normal method of valuing varying profit rentals is mathematically incorrect. The answers depends on the combination of all the variables (splitting combination, remunerate and accumulative rates adjusted for tax, the total length of term, and the manner in which it is let ). Since there are so many variables, there is no simple correction which can be applied to our normal valuation. All we can say in the final analysis is that in all cases, the answers arrived at are always too small (in our above example - always < N6,695)

The reason for this lies in the SF provisions. Theoretically a purchaser will provide one SF to cover the whole term, whereas our valuation has used two separate SFs, (One SF to recoup N5,274 or N3,204 as the case may be; and the second SF to recoup N960 or N2,890 as case may be)

The mathematically correct, but little used method of valuation of varying profit rentals is the DOUBLE SINKING FUND method. This method goes back to the firsts principle of valuation of leasehold interests i.e. there is a spendable part of a total income which by virtue of the SF will be available in perpetuity.

With respect to the above valuation.

$$
\text { Profit Rent } \quad \mathrm{N} 1000 \mathrm{pa}
$$

N6,695 x ASF to recoup NI in 21years @ $3 \%$ tax @ 40\% = N6,695 x (0.03481718 x $100 / 100-40) \_389$ Spendable income $\mathrm{N} 602=$

The sum of N389 is required to provide the necessary sinking fund leaving a spendable income of N602 =

Treating the spendable income as if available in perpetuity @ $9 \%$

$$
\begin{array}{lc}
\text { Spendable income } & \text { N602 }= \\
\text { YP perp @ 9\% } & \underline{11.11} \\
& \text { N6, } 695=
\end{array}
$$

DSF method using the 14 and 7years as in valuation II B ante

Let the capital value of interest be N C
First 14 years : Profit Rent
$\mathrm{N} 1,000 \mathrm{pa}$

Less: ASF to recoup. C in 21 yrs @ 3 \% adjusted for tax @40\%

$$
\text { Spendable income } \mathrm{N} 1000-0.059356 \mathrm{C}
$$

Treating the spendable income as if available in perpetuity, we have

$$
\underline{0.059356 \mathrm{C}}
$$

$$
\begin{aligned}
& \text { N1000 - 0.059356 C } \\
& \text { YP 14yrs @ 9\% }
\end{aligned}
$$

$\frac{7.786}{\mathrm{~N} 7786-0.46215 \mathrm{C}}$

Next 7years :

Spendable income (as above )...... N1000 - 0.059356C

YP 7yrs @ $9 \% 5.033$

PV of $\mathrm{NI}$ in 14 yrs @ 9\% $\underline{0.299}$ 
CAPITAL VALUE

\section{$\mathrm{N} 1505-0.08934 \mathrm{C}$}

$\mathrm{N} 1291-0.55149 \mathrm{C}$

But single rate YP tables make provision for replacement of capital at the remunerative rate i.e as in this case, $9 \%$ and $9 \%$ and : we have replaced our capital twice :

(a) By investing a SF @ 3\% net, adjusted for tax on income @ 40\%

(b) By using SR tables for YP, we must add back to our valuation. The PV of the capital sum which have been replaced by our use of SR table i.e N N X PV of N1 in 21yrs @ 9\%= $0.1637 \mathrm{C}$

And we have .

$$
\begin{aligned}
& \text { N7786 }-0.465215 \text { C } \\
& \text { N1505 }-0.08934 \text { C }
\end{aligned}
$$

Add Back + 0.1637 C

Given a correct C V $=$ N9291 -38779 C

By equating this to our assumed $\mathrm{CV}$ we have :

$$
\begin{aligned}
& C=N 9291-038779 \mathrm{C} \\
& \mathrm{C}=\mathrm{N} 6,695
\end{aligned}
$$

Note ; This compares exactly with the mathematically correct answer in valuation II A ante

\section{Use of ARY and RADF in Risk Adjustment}

Risk is used in those cases where a probability or weight can be attached to alternative expectations based on the comparable property information available, current and future market conditions, and specific inputs of the subject property. Uncertainty occurs where no such measure of probability can be assigned to any of the alternative

Market risks, which is our primary concern in this study generally related to market demands, expectations of revenue, yields and voids. Baum and Mackmin (1996) emphasised that a property investment may be risky when (a) rents expected in the future may not be realised (b) increase in rent may not occur at the time expected or the property becoming vacant and void (c) the capital sum invested may not be realisable, or fall with time (d) inflation rate may cause a fall in money value of property income, and (e) other property investments may out-perform the subject property. These phenomena have been technically known as business, financial, liquidity, purchasing power, management, interest rate, legislative and sector risks.

All risks yields (or risk rate) indicate the level of earnings of an investment or the speed at which the investor would earn money. It gives an indication of the degree of risk and all prospects attached to an investment. Current, reversion and term yields examples of ARY. ARY = Risk-Free Yield + Risk Factor (or Risk Premium) The rule of RADF is that the more risky an investment, the greater must be its expected return if investors are to be persuaded to undertake it. Hence the risk premium of say $1 / 2-2 \%$ is added, based on the judgment and experience of the valuer, to the risk free rate to attain an ARY. This approach is subject to variation in the valuer's personal judgment, and besides, the capacity of a single yield to capture all possible risks and equity requirements of an investment is less compelling. The problem is that $A R Y$ is non-probabilistic whereas uncertainty and risks are probability-driven.

Baum (1988) and Ogunba and Ojo (2007) restated that since individual investors are concerned with minimising risks, valuers are to seek to reflect adequately the market's view of the risks relating to their specific properties. Approaches by valuers to reflect risks in investment valuations, according to Baum (1988) and Ajayi (1998) Ogunba and Ojo (2007) are the Risk-Adjusted Discount Rate (RADF), Sensitivity Analysis, Expected Net Present Value, Standard Deviation Technique, Monte-Carlo Simulation, Certainty Equivalent Cash Flow, Stochastic Decision Tree, Sliced Income Approach, and Portfolio Theory. In the views of Ogunba and Ojo (2007) also shared by the researcher, risk adjustment approaches have the advantage of pointing out to the client that the valuers' estimates could be subject to volatility, while also providing an indication of the degree of that volatility particularly in unstable market situations. They may also be a way of avoiding the charge of inaccuracy under volatile conditions.

\section{Use of Implicit Income Capitalisation}

A major source of irrationality and perhaps, inaccuracies in valuation, according to Baum and Crosby (1988 and 1995) and Baum and Macgregor (1992) is in the concept of the conventional investment valuation as a method. Rising rental 
income is now a reality both in UK and Nigeria and it is therefore natural for investors to expect income growth. More so, expectations and anticipation is a cardinal principle of property valuation. The capitalisation rate, which is the all-risks yield did not capture investors' expectation of income growth thus making the valuation illogical and contributory to irrationality. In view of this, Ogunba and Ojo (2007) observed that it is illogical to capitalise the term rent that is fixed at an all risks market-derived yield where the yield reflected a no-income growth expectation of investors, whereas the investors expect growth after the term. Similarly, the use of the reversionary full rental value as market rental value as at the date of valuation instead of reflecting growth in the rental value to the date of reversion also became irrational.

Rational valuation models namely (i) Growth-explicit DCF such as formulated in Greaves (1972) and developed by Marshall's Equated Yield Analysis (Marshall, 1976) (ii) Sykes' Rational Valuation Model (Sykes, 1981) and Crosby's Real Value Approach (Crosby, 1983) have been proposed..

\section{Lack of Environmental Considerations}

Physico-economic development is undertaken at the expense of the environment and we cannot afford to look the other way. If we do, we invite grave consequences in the form of ecological disturbances and acute diseases. Valuers should play complementary and supportive, if not direct cardinal roles in costs internalisation. One of such roles is to identify and incorporate in their valuations, measures which encourage industrial process investors to account for externalities. An industrial process that impacts negatively on its immediate environment should not be assessed solely on the basis of its being well designed, its efficiency of operation and adequate potential profitability, but by also incorporating an eco-factor predicated on measuring the weighted ability of the industrial process to minimize adverse environmental impacts or by making pollution tax a prime factor in 'environmental' obsolescence. This will make their valuations more efficient and rational

Suppose a prosperous industrial process comprising of LBS, and PME operating in the suburb of a town complied with other regulations but lacked pollution prevention equipment, has no monitoring unit, no contingency plan and pollution response machinery, and the average depreciation rate is $30 \%$ for all PME. Let us assume that the value of land and buildings is N20m and the DRC of PME is N180m.
Pollution prevention equipment
Monitoring Unit
Pollution response machinery
No contingency plan
Rate of non-compliance
Rate of compliance

\begin{tabular}{lll}
20 & \multicolumn{2}{l}{$(0.20)$} \\
& 15 & \\
& 15 & $(0.15)$ \\
15 & $(0.15)$ & \\
5 & $(0.05)$ & \\
$55 \%$ & $(0.55)$ & $(y)$ \\
$45 \%$ & $(0.45)$ & $(x)$ \\
\hline \hline
\end{tabular}

$100 \%(1.00)$

$$
\begin{aligned}
& \text { E-Factor }=\quad \text { Average depreciation rate for PME } \quad X(1-\mathrm{x}) \\
& \text { Where } \mathrm{x}=\underline{\text { Rate of Compliance }} \\
& 100 \\
& \text { E-Factor }=30 \times(1-45 / 100) \\
& =30 \times 0.55=16.5 \% \text { or } 0.165
\end{aligned}
$$

An assessment of this industrial process as a going concern will be considered eco-compliant if the total business value of the PME is derated by $16.5 \%$ to take account of environmental obsolescence.

An eco-compliant value of the going concern will then be as follows:
(a) Value of LBS
(b) Value of PME
N 20,000,000
$\mathrm{N} 180,000,000$
less: Eco-Factor @ $0.165 \quad \mathrm{~N} 29,700,000 \quad \frac{N 150,300,000}{N 170,300,00}$
$\mathrm{N} 170,300,000$

The going concern value of the industrial process will then be N170,300,000 instead of N200,000,000= 


\section{Concluding Remarks}

This paper recommends the mandatory application of rational investment valuation models for market valuations rather than depend on non-risk and non-rental growth adjustment methods based on substitution. It is high time we started embracing DCF models that capitalise the fixed income term at the equated yield, e, and will also capture the growth of reversionary income instead of using market derived yield, $k$, and today's estimates of FRV for a future reversion. This task is put before NIESV and ESVARBON in order to enhance valuation reliability and rationality.

The implication of not taking the appropriate steps immediately is to be prepared for imminent confrontation with investors and valuation service users who are getting increasingly dissatisfied with conventional investment valuation approaches.

A reliable property data bank that can provide property indices, accuracy tests, and performance measurement similar to the UK (IPD) should either be set up by NIESV or private-sector driven. More researches should be sponsored in all the direction that will improve the valuers' valuation methods.

Development policy makers have become more aware that failing to take costs of environmental damages into account will prove to be inefficient, and then, ineffectual in raising incomes and the well being of citizens (Morvaridi,1996) Due to the failure of the market to take care of the interests of those being hurt, it is necessary for policy framework for environmental management and the promotion of development to be cognizant of factors such as the role of industrial and commercial properties, the manner of articulating and enforcing public interests and legal arrangements for enforcing liabilities, among others.

Environmental impacts of industrial processes affect property values. Our valuation of going concern industrial process do not provide for obsolescence arising as a result of adverse environmental impacts of the industrial process operations which impose huge social costs on the people. The Eco-Factor input is required to account for these impacts.

Accordingly it is recommended to the Nigerian Institution of Estate Surveyors and Valuers, through the Professional Practice Committee, to study all previous valuation approaches and fine tune to make them relevant to present day demands.

Environmental protection by industrial process investors is not reflected through the price mechanism but manifests as increased private costs to other people and increased social costs to the community in general, without corresponding social benefit to them. This scenario presents negative externalities which should be 'taxed' to internalize them, not subsidized as is the case today. Follow-up researches on the necessity for valuation to be environmentfriendly is very necessary now, for this is trend of the new environment order.

Finally, environmental obsolescence is a necessary valuation factor input that will enhance valuers' credibility and sustain their relevance in this decade and beyond. Other professional bodies such as Nigerian Society of Engineers, Nigerian Institute of Quantity Surveyors, Nigerian Institute of Town Planners, and the Nigerian Institute of Surveyors are enjoined to examine areas in their practice where adverse impacts on the environment can be identified and accounted for .

Summary of the Flaws:

(1) The use of the ARY i.e. base yield (Risk-free yield) + risk premium

(2) Overvaluation of the term in a term and reversion valuation

(3) FRV used is as at today

(4) Undervaluation of the revision

(5) Valuation not explicit about growth rates

(6) Use of two rates in the same investment

(7) Incidence of reverse yield gap (RYG is the difference between rule of thumb yield (RTY) and market yield)

(8) Use of valuation table based on rent payment in arrears, whereas rents are paid in advance

(9) Risk premium allowance (of between $0.5 \%$ to $2.5 \%$ ) when using RADF is subjective

Interest in land under the Land Use Act is limited to term of years, but this is generally treated as freeholds

\section{Bibliography}

Adair, A.S, Hutschinson, N.E., Macgregor, BD, McGreal, S, Nanthakumaran, N.(1996). An analysis of valuation variation in the UK commercial property market, Journal of Valuation and Investment, 14 (5):34-47

Babawale, G.K (2007). Valuers' liability for negligence. The Estate Surveyor and Valuer, 30 (1):49-56 
Babawale, G.K. \& Koleoso, H. (2006), Real Estate Valuation Practice in Nigeria: Implication in a Globalization World", Paper Presented at the International Conference on the Built Environment: Innovation, Policy, and Sustainable Development, Covenant University, Ota, Nigeria

Baum, A and Crosby, N (1988). Property investment appraisal, Routledge, London

Baum, A and Macgregor, B (1992). The initial yield revealed: Explicit valuations and the future of property investments. Journal of Property Valuation and investment. 10 (4):709-726

Baum, A and Crosby, N (1995) Property investment appraisal, Routledge, London, $2^{\text {nd }}$ edition

Baum, A and Mackmin, D.(1996). The income approach to property valuation, 3rd ed, Thompson, London

Bello, O. M. (2001). The Analysis and Valuation of Investment Property in the Context of the Land Use Act (No. 6 Of 1978) Of The Federal Republic of Nigeria. LAND Management in Africa - BEST PAPER PRIZE awarded by African Real Estate Society and the Royal Institute of Chartered Surveyors, United Kingdom.

Bretten, J. and Wyatt, P.[2002] Variance in property valuations for commercial lending, Research Papers 4: 9.

Broadmap, Harry (2011). Navigating the risks and opportunities in emerging markets: Pearls, Pitfalls, and Possibilities. Marketmap, Issue 1

Carsberg Report (2002) Property valuation, Royal Institution of Chartered Surveyors,London.

Crosby, N. (2000). Valuation accuracy, variation and bias in the context of standards and expectations. Journal of Property Investment and Finance Vol. 18, No. 2.

Dugeri, T.M (2011), Evaluation of the Nigerian maturity of the property market. PHD Thesis submitted to the Department of Estate Management, University of Lagos, Nigeria.

Falade, J.B. (2005). Globalisation, culture and the Nigerian Built Environment: problem, Challenges, and Benefits. Paper delivered at the Conference on Globalisation, Culture, and the Nigerian Built Environment, Obafemi Awolowo University, lle-Ife.

Greaves, M. [1972] The investment method of valuation and analysis: An examination of some of its problems. Ph.D. Thesis, University of Reading

Gilbert, Gary D (2013). Alternative Investment: What they are. Investment and Invsting Articles, Profures Inc, Austin, Texas

Hutschinson, N., Adair, N. and Leheny, I.(2007). Property risk scoring: The report of investment risks to clients. RICS Research Paper Series, 7:1

Ibiyemi, A.O (2004). Valuation model for eco-compliance in the assessment of value-in-use for going concern industrial processes in Nigeria, The Estate Surveyor \& Valuer, 27 (1): 5-24

Ibiyemi, A.O (2007). Application of Property Valuation and Analysis to Green Buildings, Lagos Journal of Environmental Studies, 6 (1):47-54

IGBOKO, N. P. (1992). Research project on Valuation Methods in Nigeria with special reference to Years Purchase. Research report for the Nigeria Institution of Estate Surveyors and Valuers, 1 - 43.

Investment Property Forum/IPD (2000) The Assessment and Management of Risk in the Property Investment Industry, Investment Property Forum/Investment Property Databank, London. 34-47.

Leramo, G. A. (1992). The Groundwork of property valuation. Kaduna Polytechnic Press, Kaduna, 1, 1 - 3.

Lin, Zhenguo and Liu, Yingehun (2013). Real estate returns and risks with heterogeneous investors. http://google.inklineglobal.com/google_rom_search_results.html?q=What+are+the+effects+of+overstating+or+understating+prop erty+investment+risks\&cx=partner-pub-6697027465779297\%3A3144322079\&cof=FORID\%3A10\&ie=UTF-

8\&sa=Search\&siteurl=http\%3A\%2F\%2Fgoogle.inklineglobal.com\%2F\%3FMB

Marshall (1976). Equated yield analysis. Estate Gazette, 9th November, (276): 603

Matysiak, G.A and Wang, P. (1995) Commercial property market prices and valuations: analysing the correspondence, Journal of Property Research, 12(3): 181-202.

Millington A.F. [1985] Accuracy and the role of the valuer, Estate Gazette, 9thNovember, (276): 603.

Ogunba, O.A; Ajayi, C. A, and Aluko, B. T. (2005). Substitution versus anticipation:a resolution of the Nigerian Valuation Practice Paradox. Journal of Land use and Development Studies, 1, (1), 1 - 10.

Ogunba, O.A and Ojo, O. (2007). Resolving reliability, consistency and rationality problems of professionally prepared valuation in Nigerian practice. The Estate Surveyor and Valuer, 30 (1):39-48

Ogunba, O.A., Ajayi, C.A., and Aluko, B.T.(2003). Substitution vs. anticipation: A resolution of the valuation practice paradox. Journal of Land Use \& Development Studies, 1, 1-11

Ojo, O. (2004). Reliability, consistency and rationality of professionally prepared valuations: Suggestions for resolving the problems in Nigerian practice. CPD Training Workshop. Organised by the NIESV in Lagos, Kaduna and Enugu

Sykes, S. (1981). Property valuation: A rational model. The Investment Analyst. .61:20-26

Umezurike, O. N. (1989). The land use Decree, 1978: A Critical Analysis. FAB Educational Books, Jos, Nigeria.

White, J.R.(1987). The real estate appraisers - The elusive goal of professionalism. The Appraisal Journal, July, 325-377

Waldy, B (1997). Valuation accuracy, $6^{\text {th }}$ FIG permanent committee meeting and international symposium, Singapore

Wood, E. (1972): Property investment: A real value approach. Ph.D.Thesis, University of Reading 